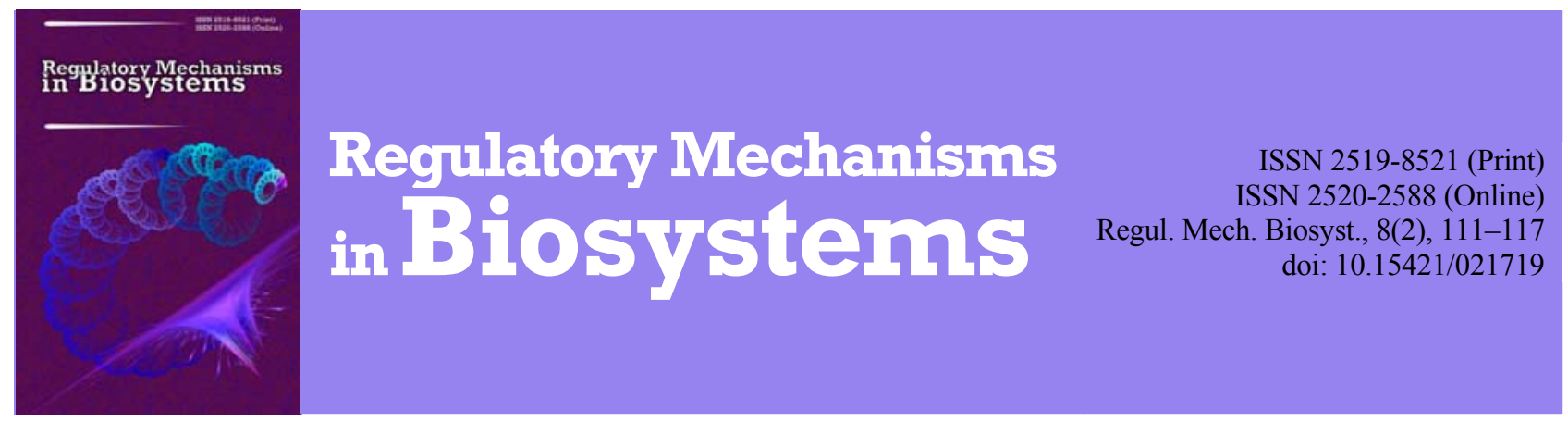

\title{
Condition of erythrocyte membranes in people with mental and behavioural disorders caused by alcohol consumption
}

\author{
O. V. Baskevich \\ Precarpatian National University named after V. Stefanik, Ivano-Frankivsk, Ukraine
}

Article info

Received 21.02.2017

Received in revised form 30.03.2017

Accepted 03.04.2017

Precarpatian National University named after $V$. Stefanik, Shevchenko Str., 57 , Ivano-Frankivsk, 76025, Ukraine Tel.: +38-097-87-41-446 E-mail:basgala@gmail.com
Baskevich, O. V. (2017). Condition of erythrocyte membranes in people with mental and behavioural disorders caused by alcohol consumption. Regulatory Mechanisms in Biosystems, 8(2), 111-117. doi:10.15421/021719

We studied the morphological features of the restructuring and osmotic stability of erythrocytes of 30 people with mental disorders and disorders of behavioral reactions caused by 5-7 years consumption of alcohol, the objects of the research being in a state of abstinence during the period of the investigation,. The study of quantitative composition of red blood cells and hemoglobin, as well as their ratio in people with mental and behavioural disorders developed as a result of alcohol consumption showed a decrease in the number of red blood cells and hemoglobin of $42.2 \%$ and $25.1 \%$, respectively, indicating the presence in those people of anemic hypoxia. This is closely correlated with a decrease of osmotic resistance of red blood cells to different concentrations of sodium chloride solutions, whereby the state of erythrocyte membranes deteriorates and their resistance to hemolysis decreases. Parallel to this, is a reduction in the size of red blood cells coupled with a variety of changes in their microrelief. Conformational changes of erythrocytes are closely correlated with changes in the activity of enzymes responsible for the biotransformation of xenobiotics, primarily products of lipid peroxidation. It is shown that activity of the erythrocyte antioxidant defense system is sharply reduced as a result of increase in partially oxidized products of metabolism. It was found that the state of red blood cells is a sensitive indicator of the normal course of physiological changes, biochemical and biophysical processes in the bodies of people with mental disorders and behavior reactions developed due to consumption of alcohol.At the same time, the measurement of the osmotic resistance of red blood cells and changes in the shape of red blood cells connected with this phenomenon is an important research method for studying mechanisms of pathological processes and the action of certain drugs or biologically active substances, expands the possibilities of establishing the depth of destruction of body tissues, and also provides excellent opportunities for researchers to identify the effectiveness of treatment and prevention for people with mental disorders and behavior reactions caused by consumption of alcohol. This article discusses prospects of studies of the level of glutathione peroxidase activity in the erythrocytes among people with mental and behavioural disorders as a marker of highly specific homeostasis in the human body in response to long-term alcohol consumption, and considers using this index as a criterion for selecting patients for different groups of physical rehabilitation and recreation according to the level of rehabilitation potential.

Keywords: erythrocyte; mental and behavioral disorders; alcohol; structure; osmotic resistance; antioxidant protection

\section{Стан мембран еритроцитів у людей із розладами психіки та поведінки внаслідок вживання алкоголю}

\author{
О. В. Баскевич
}

\section{Прикарпатський національний університет імені Василя Стефаника, Івано-Франківськ, Україна}

У 30 людей із розладами психіки та поведінкових реакцій унаслідок вживання алкоголю, що перебувають у стані абстиненції зі стажем вживання алкоголю 5-7 років, вивчали особливості морфологічної перебудови та осмотичної стійкості еритроцитів. Дослідження кількісного складу еритроцитів і гемоглобіну, а також їх співвідношення в людей із розладами психіки та поведінки через вживання алкоголю виявило зниження кількості еритроцитів і гемоглобіну на 42,2\% і 25,1\% відповідно, що свідчить про наявність у них анемічної гіпоксії. Це тісно корелює зі зниженням осмотичної стійкості еритроцитів до різної концентрації розчинів натрію хлориду, внаслідок чого погіршується стан еритроцитарних мембран і знижується їх стійкість до гемолізу. Одночасно із цим відбувається зменшення розмірів еритроцитів у поєднанні з різними змінами їх мікрорельєфу. Конформаційні зміни еритроцитів тісно корелюють зі змінами активності ферментів і відповідають за біотрансформацію ксенобіотиків, перш за все продуктів перекисного окиснення ліпідів. При цьому показано, що активність системи антиоксидантного захисту еритроцитів різко знижується на тлі збільшення недоокиснених продуктів метаболізму. Стан еритроцитів - чутливий індикатор змін нормального перебігу фізіологічних, біохімічних та біофізичних процесів в організмі людей із розладами психіки та поведінки через вживання алкоголю. При цьому встановлення осмотичної стійкості еритроцитів і поєднані з цим явищем зміни форми еритроцитів - важливий метод дослідження для вивчення механізму патологічних процесів і дії деяких ліків або 
біологічно активних сполук, що розширює можливості встановлення глибини ураження тканин організму, а також дає можливість широкому колу дослідників виявляти ефективність лікувально-профілактичних заходів для людей із розладами психіки та поведінки через вживання алкоголю. Обговорюється перспективність досліджень у людей із розладами психіки та поведінки рівня активності глутатіонпероксидази в еритроцитах як високоспецифічного маркера порушення гомеостазу в організмі людини у відповідь на тривале вживання алкоголю та використання цього показника як критерію відбору за рівнем реабілітаційного потенціалу таких пацієнтів в окремі групи фізичної реабілітації та рекреації.

Ключові слова: еритроцит; розлади психіки; розлади поведінки; алкоголь

\section{Вступ}

Нині в усьому світі гостро стоїть проблема лікування, профілактики та поліпшення якості життя людей із розладами психіки та поведінки внаслідок вживання алкоголю. Вживанню алкоголю та наркотиків сприяє низка факторів, серед яких найістотнішй - нестабільна соціальна обстановка, економічна криза, зміни особистісних цінностей, критичні періоди вікового розвитку тощо (Billieux, 2014; Chernaia et al., 2016). Дані різних дослідників вказують, що загальна кількість людей, які зловживають алкоголем, становить $2,8-5,0 \%$ населення Землі (Leggio, 2011; Chick, 2014). При цьому основна «група ризику» виникнення розладів психіки та поведінки внаслідок вживання алкоголю складається на 89,7\% із людей до 30 років (Ко, 2014; Kurniasanti, 2014).

Постійне надходження в організм алкоголю чи інших наркотичних речовин запускає різні патологічні стрес-реакції, які активізують процеси метаболізму та спричинюють розвиток психічної та фізичної залежності (Nielsen et al., 2012; Koob, 2014). За тривалого стресу виникають стійкі порушення обміну речовин в організмі, які згодом можуть викликати різні захворювання. Як наслідок, спостерігається зниження рівня захисних сил організму, знижується також рівень соціальної активності людини, iï працездатність і адекватність поведінки (Rehm \& Poznyak, 2015; Moskalewicz et al., 2016).

Результати досліджень окремих авторів (Najafipour \& Beik, 2016) свідчать про те, що алкоголь і наркотичні речовини створюють умови для інтенсифікації процесів вільнорадикального окиснення, які, у свою чергу, зумовлюють розвиток оксидативного стресу. Більшість продуктів вільнорадикального окиснення провокує окисну деструкцію клітинних мембран (Welle-Strand, 2014).

Утворення продуктів вільнорадикального окиснення ключовий етап патогенезу багатьох захворювань, і алкогольної залежності зокрема. Алкоголь впливає на основні стадії внутрішньоклітинного метаболізму глюкози, процеси енергетичного, ліпідно-білкового обміну та стосується переважно аеробного окиснення вуглеводів та жирних кислот (González-Alonso, 2012; Foroughi et al., 2016). Внаслідок цього розвивається ліпофільно-лізуючий ефект алкоголю та наркотиків, мішень якого клітинна мембрана еритроцитів. При цьому змінюються рідинно-кристалічна структура і такі основні властивості клітинних мембран як в'язкість, стійкість при жорстко-еластичних деформаціях. Це супроводжується пригніченням усіх функцій і не тільки передчасним відмиранням еритроцитів, а й старінням організму в цілому (Oslin, 2011).

Якісні та кількісні показники крові, метаболічні зрушення в іiї компонентах несуть інформацію про індивідуальну реактивність, а їх комплексна оцінка здатна дати адекватне уявлення про рівень адаптаційних можливостей цілого організму (Наjela, 2014). Системна патологія, що розвивається за тривалого вживання алкоголю, зокрема, під час пошкодження еритроцитів (одного з найчутливіших до дії цієї речовини типу клітин), робить актуальним пошук нових способів виявлення змін на рівні цілого організму у вигляді мембранопатій і можливостей системної коригувальної дії, зокрема, в системі фізичної реабілітації людей з розладами психіки та поведінки через вживання алкоголю (Raheb et al., 2016).

Оскільки вживання алкоголю дуже поширене серед людей різного віку, в численних публікаціях показано, що в людей із розладами психіки та поведінки внаслідок вживання алкоголю часто спостерігаються всі ознаки нейродегенеративного захворювання, яке прогресує досить швидко та клінічно виявляється не тільки у порушенні соматичного здоров'я, а й у поступовій втраті пам'яті та розумових здібностей, тобто зниженні рівня психофізичного стану. Патогенез хвороби залишається не визначеним, а діагностика заснована, в основному на суб' єктивних ознаках, при існуванні багатьох способів лікування їх результати досить проблематичні та невизначені 3 огляду на сприятливість і прогностичність віддалених результатів. Діагностика в людей розладів психіки та поведінки через вживання алкоголю базується на виявленні токсичних компонентів, серед яких на першому місці визнані продукти перекисного окиснення ліпідів. Відповідно до гіпотези оксидативного стресу, їх накопичення у тканинах ініціює каскад реакцій, який спричинює складну патологію та клінічні прояви хвороби (Khalsa, 2014). Нерозчинні комплекси фібрилярних білків та їх розчинні олігомери стимулюють продукцію активних кисневмісних метаболітів, указуючи на зв'язок між ïх накопиченням, окисним стресом і загибеллю різних клітин організму (Koivu, 2014).

Багаторічні дослідження показали, що у людей із розладами психіки та поведінки внаслідок вживання алкоголю аномалії в окисних процесах спостерігаються як у мозку (Eve et al., 2016), так i в інших тканинах і клітинах (Bergamini et al., 2004). При цьому вражаються не лише центральна нервова система, а й периферичні тканини, зокрема еритроцити (González-Alonso, 2012).

У патогенезі зазначених розладів психіки та поведінки першорядну роль відіграють вік пацієнта та окисний стресс у різних клітинах. Еритроцити розглядаються як пасивні «клітини інформатори», що відображають біохімічні процеси, які відбуваються в організмі (Foroughi et al., 2016). Проте конформаційні зміни еритроцитів у таких людей майже не вивчені, недостатньо відомостей про окиснювальний стрес у цих клітинах, а наявні дані надзвичайно суперечливі. Залишаються мало відомими дані про концентрацію перекису водню та органічних гідропероксидів в еритроцитах, їх зміни залежно від дози та тривалості вживання алкоголю, а також взаємозв'язок із віком і при різних видах наркоманії та алкоголізмі. Існують поодинокі праці (Wigmore, 2009), які стосуються результатів вимірювання внутрішньоклітинних концентрацій відновленого глутатіону та окисненого глутатіону або глутатіондисульфіду в людей із розладами психіки та поведінки внаслідок вживання алкоголю.

Мета цього дослідження - оцінити біохімічні показники системи антиоксидантного захисту та осмотичну стійкість еритроцитів у взаємозв'язку з особливостями їх морфологічної перебудови у людей $з$ розладами психіки та поведінки через вживання алкоголю.

\section{Матеріал і методи досліджень}

Дослідження проводили на базі наркологічного відділення обласного психо-неврологічного диспансеру (м. Івано-Франківськ). До складу експериментальної групи входили 30 людей 3 розладами психіки та поведінки внаслідок вживання алкоголю, які виявили власну (чи найближчих родичів) згоду у письмовій формі. Діагноз розладів психіки та поведінки базувався на критеріях Стандартів медичних технологій, розроблених на виконання доручення Президента України від 04.03.1998 р. № 1-14/147 3 метою уніфікації вимог до обсягів і якості медичної допомоги в лікувально-профілактичних закладах України, затверджені наказом Міністерства охорони здоров’я України № 226 від 17.07.1998 р. 
Як контроль брали кров 10 практично здорових людей, які проходили медичне обстеження для отримання різних дозвільних документів (водійські права, дозвіл на володіння зброєю тощо). Здорові добровольці контрольної групи відібрані за відсутності в аннамнезі хронічних захворювань, неврологічних або психіатричних порушень, чи терапії, пов'язаної з такого роду захворюваннями.

Загальним аналізом крові визначали осмотичну стійкість еритроцитів (Renwick \& Asker, 2008) та їх гісто-ультраструктурну будову. Морфологічні дослідження проводили у фазово-контрастному мікроскопі та на сканувальному електронному мікроскопі JEOL-25M-T220A (Японія) за загальноприйнятими методиками 3 визначенням мікроелементного складу еритроцитів. Біохімічні дослідження проводили згідно з рекомендаціями Wigmore (2009).

Отримані дані піддавали комп'ютерній варіаційно-статистичній обробці методом малої вибірки за допомогою статистичного пакета Statistica 6 (StatSoft Inc, USA). Використовували непараметричні методи дослідження (критерій Уїлкоксона, Манна - Уїтні). Вибіркові параметри, наведені далі в таблицях i тексті, мають такі позначення: $x$ - вибіркове середне, SE стандартна помилка середнього. Відмінності вважали статистично вірогідними за $\mathrm{P}<0,05$ і нижче.

\section{Результати}

Результати досліджень виявили значні зміни показників крові у людей із розладами психіки та поведінки внаслідок вживання алкоголю (табл. 1).

\section{Таблиця 1}

Різниця окремих показників крові у людей контрольної та експерименальної групи (x $\pm \mathrm{SE})$

\begin{tabular}{lcc}
\hline \multicolumn{1}{c}{ Показники крові } & $\begin{array}{c}\text { Контрольна група, } \\
\mathrm{n}=10\end{array}$ & $\begin{array}{c}\text { Експериментальна } \\
\text { група, } \mathrm{n}=30\end{array}$ \\
\hline Еритроцити ( $\left.{ }^{\mathrm{x}} 10^{12} / л\right)$ & $4,5 \pm 0,17$ & $2,6 \pm 0,02^{*}$ \\
Гемоглобін (г/л) & $120,0 \pm 3,24$ & $90,0 \pm 10,43^{*}$ \\
Кольоровий показник & $0,81 \pm 0,001$ & $1,31 \pm 0,001^{*}$ \\
Швидкість осідання & $11,4 \pm 1,02$ & $7,4 \pm 0,92 *$ \\
еритроцитів (мм/год) & &
\end{tabular}

Примітка: * - $\mathrm{P}<0,05$ щодо контрольної групи.

Порівняно з людьми контрольної групи в експериментальній групі загальна кількість еритроцитів знижується на 42,2\%, що тісно корелює $(\mathrm{r}=0,82)$ зі зниженням на $25,0 \%$ рівня гемоглобіну $(\mathrm{P}<0,05)$. При цьому кольоровий показник у людей із розладами психіки та поведінки внаслідок вживання алкоголю збільшується на $28,7 \%$, а швидкість осідання еритроцитів знижується на $35,1 \%$, залишаючись на рівні нижньої межі фізіологічної норми.

Порівняно $з$ контрольною групою, у людей експериментальної групи спостерігається зниження кількості еритроцитів (табл. 2) на $42,2 \%$ (у $3,0 \%$ розчині хлориду натрію), на $28,6 \%$ (у $0,5 \%$ розчині хлориду натрію), на $46,2 \%$ (за концентрації розчину натрію хлориду $0,46 \%$ ) і на $54,5 \%$ (за $0,3 \%$ розчину хлориду натрію). Результати нашого дослідження вказують на зниження стійкості еритроцитів у людей експериментальної групи за збільшення площі поверхні їх цитоплазматичної мембрани. Це добре можна прослідкувати на прикладі структурної перебудови, яку ми спостерігали у процесі дослідження еритроцитів різними морфологічними методиками (рис. 1, 2).

\section{Таблиця 2}

Показники осмотичної резистентності еритроцитів за різних концентрацій розчину хлориду натрію $(\mathrm{x} \pm \mathrm{SE})$

\begin{tabular}{ccc}
\hline Концентрація & $\begin{array}{c}\text { Контрольна група, } \\
\mathrm{n}=10\end{array}$ & $\begin{array}{c}\text { Експериментальна } \\
\text { група, } \mathrm{n}=30\end{array}$ \\
\hline $3,00 \%$ & $4,5 \pm 0,09$ & $2,6 \pm 0,04^{*}$ \\
$0,50 \%$ & $2,0 \pm 0,04$ & $1,5 \pm 0,08^{*}$ \\
$0,46 \%$ & $1,5 \pm 0,01$ & $0,7 \pm 0,03 *$ \\
$0,30 \%$ & $1,1 \pm 0,01$ & $0,6 \pm 0,01^{*}$ \\
\hline
\end{tabular}

Примітка: див. табл. 1.
Порівняно 3 контрольною групою, у людей експериментальної групи вміст 2,3-дифосфогліцерату та лактату вірогідно $(\mathrm{P}<0,05)$ зростає на $42,5 \%$ i $51,6 \%$, а концентрація піровиноградної кислоти знижується на $51,7 \%$ (табл. 3). При цьому активність супероксиддисмутази підвищується на $61,2 \%$, тоді як активність каталази зменшується на 16,8\% (табл. 4). Зменшується вміст відновленого глутатіону на фоні зниження активності глутатіонредуктази та глутатіонпероксидази (табл. 5).

\section{Таблиця 3}

Вміст 2,3-дифосфогліцерату, піровиноградної кислоти та лактату в еритроцитах людей контрольної та експериментальної групи $(\mathrm{x} \pm \mathrm{SE})$

\begin{tabular}{|c|c|c|c|}
\hline \multirow[b]{2}{*}{ Група } & \multicolumn{3}{|c|}{ Показники, ммоль/л } \\
\hline & $\begin{array}{c}\text { 2,3-дифо- } \\
\text { сфогліцерат }\end{array}$ & $\begin{array}{c}\text { піровиноградна } \\
\text { кислота }\end{array}$ & лактат \\
\hline Контрольна група, $\mathrm{n}=10$ & $7,02 \pm 0,24$ & $1,14 \pm 0,02$ & $4,34 \pm 0,12$ \\
\hline $\begin{array}{l}\text { Експериментальна група, } \\
\mathrm{n}=30\end{array}$ & $10,01 \pm 0,67^{*}$ & $0,55 \pm 0,003^{*}$ & $6,58 \pm 0,14^{*}$ \\
\hline
\end{tabular}

Примітка: див. табл. 1.

\section{Таблиця 4}

Активність супероксиддисмутази (од./г Нb)

і каталази $\left(\times 10^{4} / \Gamma \mathrm{Hb}\right)$ в еритроцитах людей контрольної та експериментальної групи $(\mathrm{x} \pm \mathrm{SE})$

\begin{tabular}{lcc}
\hline \multicolumn{1}{c}{ Група } & \multicolumn{2}{c}{ Показники } \\
\cline { 2 - 3 } & супероксиддисмутаза & каталаза \\
\hline Контрольна група, $\mathrm{n}=10$ & $634,3 \pm 8,6$ & $482,9 \pm 4,5$ \\
Експериментальна група, $\mathrm{n}=30$ & $1022,3 \pm 12,6^{*}$ & $401,8 \pm 4,0^{*}$ \\
\hline
\end{tabular}

Примітка: див. табл. 1.

\section{Таблиця 5}

Вміст відновленого глутатіону

та активність ферментів його обміну в еритроцитах людей контрольної та експериментальної групи $(\mathrm{x} \pm \mathrm{SE})$

\begin{tabular}{lccc}
\hline \multirow{2}{*}{ Група } & \multicolumn{3}{c}{ Показники } \\
\cline { 2 - 4 } & $\begin{array}{c}\text { глутатіон, } \\
\text { ммоль/ } \\
\mathrm{Hb}\end{array}$ & $\begin{array}{c}\text { глутатіон- } \\
\text { редуктаза, } \\
\text { ммоль/г Hb } \\
\text { на хвилину }\end{array}$ & $\begin{array}{c}\text { глутатіон- } \\
\text { пероксидаза, } \\
\text { ммоль } / \Gamma \mathrm{Hb} \\
\text { на хвилину }\end{array}$ \\
\hline $\begin{array}{l}\text { Контрольна група, } \mathrm{n}=10 \\
\begin{array}{l}\text { Екпериментальна група, } \\
\mathrm{n}=30\end{array}\end{array}$ & $2,77 \pm 0,11$ & $4,65 \pm 0,11$ & $353,88 \pm 3,26$ \\
\hline
\end{tabular}

Примітка: див. табл. 1.

\section{Обговорення}

Якісно-кількісні характеристики еритроцитів у людей із розладами психіки та поведінки внаслідок вживання алкоголю залежать від багатьох факторів, загальний механізм дії яких виражається в розвитку гіпоксичних станів (Bianchini \& Wright, 2013). Такими факторами можуть виступати токсичні речовини, наприклад алкоголь і наркотичні речовини, які викликають найрізноманітніші порушення метаболізму в організмі людини (Hajela, 2014). Широко відома роль цих речовин у порушеннях імунної, серцево-судинної системи, органів травлення, а також патогенезі алкоголізму та наркоманії, лімітації стрес-реакції в центральній нервовій системі та периферичних органах, спотворенні антиноціоцептивної чутливості (Nielsen et al., 2012; Khalsa, 2014; Kurniasanti, 2014).

Стан мембрани еритроцитів - чутливий індикатор змін нормального перебігу фізіологічних, біохімічних та біофізичних процесів в організмі, зумовлених впливом факторів зовнішнього середовища, у тому числі психогенних, до яких належить вживання алкоголю та різні види наркоманій (Bunt, 2014).

Визначення осмотичної стійкості еритроцитів і поєднані 3 цим явищем зміни їх форми - важливий метод дослідження у біології та діагностики в медицині, а також часто використовується для вивчення механізму патологічних процесів та дії деяких ліків або біологічно активних сполук (González-Alonso, 2012). 


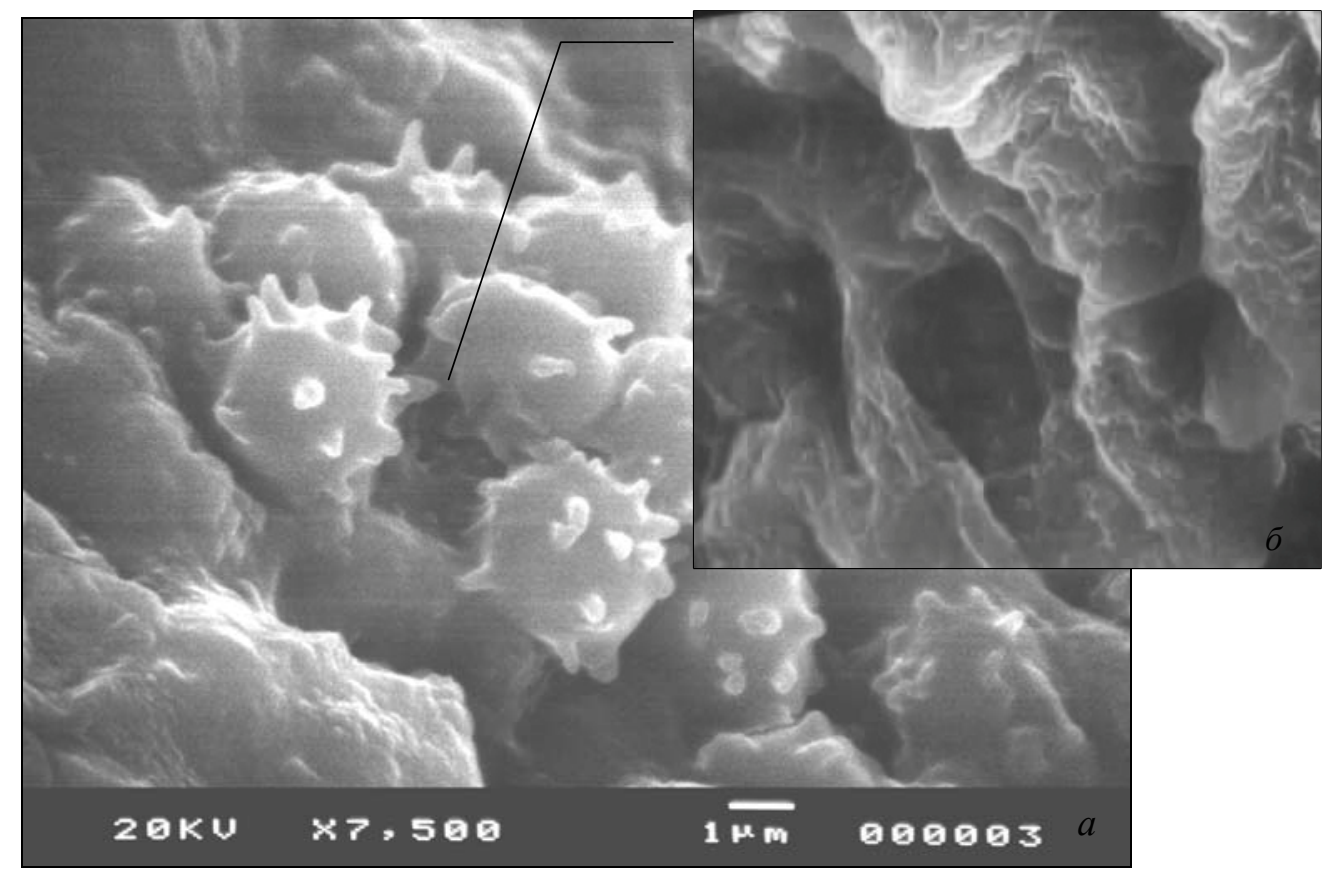

Рис. 1. Зміна поверхневого мікрорельєфу еритроцитів у пацієнта А., вік 35 років (історія хвороби № 24462/14): спостерігається збільшена кількість ехіноцитів (a) та утворення широких мембранних пор (б); сканувальна електронна мікроскопія: $a-{ }^{\mathrm{x}} 7500,6-{ }^{\mathrm{x}} 50000$

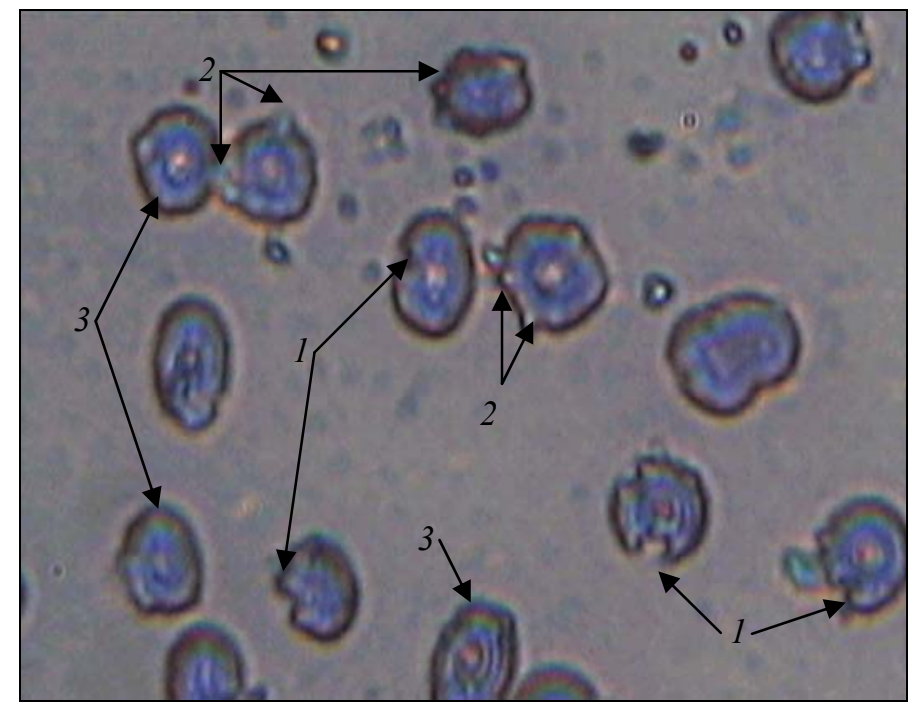

Рис. 2. Структурні перетворення еритроцитів периферичної крові пацієнта А., вік 35 років (історія хвороби №24462/14): 1 - «узуровані» клітини, 2 - шипуваті клітини, 3 - клітини-«мішені»; фазово-контрастна темнопольна мікроскопія, ${ }^{\times} 4800$

Виявлене нами збільшення кольорового показника у людей із розладами психіки та поведінки внаслідок вживання алкоголю вказує на нормохромний тип анемії (Ainul, 2017), а зниження швидкості осідання еритроцитів до рівня нижньої межі фізіологічної норми вказує, що система крові реагує не тільки кількісними, а і якісними змінами свого складу на вплив несприятливих факторів із метою підтримання гомеостазу (у нашому випадку, токсичний вплив продуктів метаболізму етанолу та речовин, що утворюються внаслідок порушення обміну нутрієнтів після тривалого вживання алкоголю) (Khalsa, 2014).

Зниження стійкості еритроцитів можна пояснити тим, що у людей із розладами психіки та поведінки через вживання алкоголю токсичні сполуки включаються в ліпідний шар клітинних мембран і збільшують площу поверхні їх цитоплазматичної мембрани. Це добре можна прослідкувати на прикладі структурної перебудови, яку ми спостерігали під час дослідження еритроцитів різними морфологічними методами. Нині алкоголь залишається одним із поширених i доступних у побуті токсичних речовин, який за своїми фармакологічними властивостями належить до наркотичних речовин жирного ряду. Провідними факторами, що визначають токсичну дію алкоголю, є його мембранотоксичний ефект, виснаження запасів окисненого нікотинамідаденіндинуклеотиду, утворення ацетилальдегіду та конкуренція алкоголю з іншими джерелами енергії, наприклад вуглеводами (Kutubi et al., 2016).

Алкоголь викликає розрідження клітинних мембран, зміну структури їх фосфоліпідного шару та порушення трансмембранного перенесення іонів (Kayani \& Parry, 2010). Масивне навантаження алкоголем або його хронічний прийом можуть ослабити інтенсивність окиснення в печінці багатьох інших субстратів (тригліцеридів, жирних кислот, гормонів тощо), що вимагають присутності окисненого нікотинамідаденіндинуклеотиду. Існує певна кореляція між симптомами сп'яніння та зміною напрямку метаболізму серотоніну - з окиснювального на відновний тип, який відбувається в результаті накопичення у печінці відновленого нікотинамідаденіндинуклеотиду (Hafez 
et al., 2016). Під час хронічного отруєння токсична дія алкоголю на організм виявляється широким спектром різних ефектів. Алкоголь чинить негативний вплив на метаболізм вуглеводів, викликає хвороби печінки, підшлункової залози, інших органів шлунковокишкового тракту, м'язової тканини, спричинює порушення ді. яльності ЦНС, ендокринної системи, збільшує вірогідність розвитку серцево-судинних, інфекційних захворювань і сприяє новоутворенням. Один із найважливіших аспектів токсичної дії алкоголю на організм - його вплив на кровотвірну систему (Wigmore, 2009). Токсичний вплив на гемопоез може бути наслідком прямої дії алкоголю, вторинних порушень процесу травлення або токсичного ураження печінки. За хронічного алкоголізму можливий прояв цілої низки гематологічних синдромів. Алкоголь здатний безпосередньо індукувати макроцитоз еритроцитів. Повільне зникнення макроцитозу у період абстиненції відрізняє цей феномен від інших проявів прямої токсичної дії алкоголю на гемопоез: мегало- та сидеробластних змін, вакуолізації стовбурових гемопоетичних клітин-попередників і тромбоцитопенії.

Нерідко спостерігаються анемії, що супроводжуються гемолітичним синдромом, причина яких - підвищений гемоліз еритроцитів. Такі зміни - наслідок токсичної дії алкоголю на клітини крові, ураження печінки, викликані жировою інфільтрацією та цирозом (Renwick \& Asker, 2008). Зменшується густина упаковки фосфоліпідів у мембранах еритроцитів і зростає текучість біліпідного шару в мембранах еритроцитів. Збільшується кількість холестерину та жирних кислот з індексом $18: 1$, відбувається зниження вмісту фосфатидилетаноламіну та відносної кількості жирних кислот з індексом $18: 2$. Така ж токсична дія алкоголю виявлена в мембранах клітин печінки та головного мозку. Ці зміни розглядають як адаптивні, що компенсують розріджувальну дію алкоголю на клітинні мембрани.

Зміни у складі ліпідів мембран лежать в основі молекулярних механізмів формування толерантності до алкоголю та залежності від нього. Фазовий стан рідкокристалічної структури ліпідного біошару мембрани, ступінь іiі текучості створюють істотний вплив на в'язко-еластичні властивості еритроцитів, їх здатність до деформації, на проникність мембран еритроцитів для води, на швидкість дифузії кисню через мембрани, на активність мембранозв'язаних ферментів. Відповідно розріджувальна дія алкоголю на ліпіди мембран порушує нормальне функціонування мембранних структур еритроцитів у цілому.

Флюїдизувальна (розріджувальна) дія алкоголю на мембрани еритроцитів пояснюється його вбудовою у поверхневі ділянки мембран між полярними групами фосфоліпідів. Між мембранами еритроцитів і плазмою крові відбувається постійний обмін ліпідами. Жирні кислоти, пов'язані 3 альбуміном плазми, включаються до складу фосфатидилхоліну мембран еритроцитів у ході реакцій ацилювання лізофосфатидилхоліну. Цей процес вимагає енергетичних витрат.

Надходження холестерину в мембрани еритроцитів здійснюється пасивно, тобто в мембрану еритроцитів включається тільки вільний холестерин, не пов'язаний із жирними кислотами. Рівень вільного холестерину в плазмі крові залежить від активності ферменту фосфатидилхолін-холестеринацилтрансферази, який синтезується в печінці та здійснює перенесення жирної кислоти від фосфатидилхоліну до холестерину з утворенням ефірів холестерину. Високий вміст холестерину в мембранах еритроцитів у хворих на алкоголізм пояснюють порушенням синтезу фосфатидилхолін-холестеринацилтрансферази в результаті ураження печінки. Внаслідок цього у плазмі крові зростає кількість вільного холестерину, який включається в мембрани еритроцитів.

У наших дослідженнях у людей із розладами психіки та поведінки внаслідок вживання алкоголю 3 явними ознаками ураження печінки виявлені значні зміни складу ліпідів у мембранах еритроцитів i, як наслідок, поява акантоцитів і мішенеподібних клітин. Поява еритроцитів мішенеподібної форми зумовлена підвищеним вмістом у мембранах холестерину та фосфатидилхоліну, молярне відношення холестерин / фосфолі- піди зростає на $15,0 \%$. Помірний гемоліз у людей із розладами психіки та поведінки через вживання алкоголю за появи мішенеподібних еритроцитів зумовлений наявністю портальної гіпертензії та спленомегалії, характерними для цирозу печінки. Більш виражений гемоліз зі зниженням величини гематокриту до $16,0 \%$ спостерігається в осіб із цирозом печінки при появі у крові акантоцитів - еритроцитів із нерівним контуром мембрани. У результаті зростає мікров'язкість мембран акантоцитів, погіршуються їх реологічні властивості, що ймовірно, і зумовлюють розвиток гемолітичної анемії разом із портальною гіпертензією та спленомегалією.

У людей із розладами психіки та поведінки внаслідок вживання алкоголю $з$ ураженням печінки можуть 3'являтися еритроцити 3 ротоподібною смугою та проясненням у центрі, так звані стоматоцити, які під час сканувальної електронної мікроскопії мають вигляд товстостінної чаші. Середній об'єм стоматоцитів достовірно збільшений. Вміст холестерину, триацилгліцеридів, ціанкоболаміну, фолієвої кислоти у крові таких пацієнтів немає залежності від наявності чи відсутності стомацитів.

Трансформацію дискоцит-стоматоцит викликають агенти, що блокують роботу кальцієвого насосу еритроцитів. У результаті в їх цитоплазмі зростає концентрація іонів кальцію, що спричинює агрегацію молекул білка спектрину, локалізованого на цитоплазматичній поверхні мембрани. Для деформації мембрани стоматоцита потрібне велике зусилля порівняно $з$ мембраною дисокоцита.

Про важливу роль процесів перекисного окиснення ліпідів у механізмі пошкодження еритроцитів у випадку вживання алкоголю свідчать результати дослідження (Miller, 2012), які виявили низький рівень альфа-токоферолу у плазмі крові та ліпідах мембран еритроцитів у людей із розладами психіки та поведінки внаслідок вживання алкоголю та синдромом Циве, а також зниження в них кількості відновленого глутатіону, аденозинтрифосфорної кислоти, 2,3-дифосфогліцерату, нестабільність піруваткінази та низьку стійкість клітинниої мембрани до перекисного гемолізу.

Для синдрому Циве у людей із зазначеними розладами психіки та поведінки характерні помірна анемія, гіпербілірубінемія, жирова інфільтрація та незначні зміни функції печінки. Гемоліз еритроцитів пояснюють збільшенням у плазмі крові кількості лізоформ фосфоліпідів, вільних жирних кислот і стероїдів. У процес перекисного окиснення у першу чергу залучаються молекули фосфоліпідів, до складу яких входять ненасичені жирні кислоти. При цьому зростає мікров'язкість мембран, зменшується їх текучість. Це дозволяє розглядати активацію процесів перекисного окиснення ліпідів як швидку компенсаторну реакцію, що забезпечує впорядкованість структури мембран еритроцитів за лізуючої (флюїдизуючої, розріджувальної) дії алкоголю.

Цитоскелет мембрани еритроцитів - міцна, гнучка, еластична сітка, утворена білками на внутрішній поверхні ліпідного біошару мембрани еритроцитів. Це важлива функціональна структура, яка визначає в'язкість і еластичні властивості мембран еритроцитів. Порушення метаболізму еритроцитів, зниження рівня аденозинтрифосфорної кислоти, відновленого глутатіону супроводжуються змінами з боку цитоскелета еритроцитів, утворенням макромолекулярних білкових агрегатів, низькою здатністю еритроцитів до деформації і стаєть причиною розвитку гемолітичних анемій.

Значення фазового стану мембрани, ступінь їі текучості для нормального функціонування еритроцитів дозволяють розглянути активацію процесів перекисного окиснення ліпідів, зміни ліпідного складу мембран (збільшення відношення холестерин / фосфоліпіди, зменшення вмісту ненасичених кислот), зниження кількості мембранозв'язаних гліканів за дії алкоголю, як адаптивні, що компенсують розріджувальну дію алкоголю на мембрани еритроцитів. Проте подібні зміни негативно позначаються на активності мембранозв'язаних ферментів, метаболізмі та реологічних властивостях еритроцитів, що посилюється пошкодженнями печінки та порушеннями ліпідного обміну. Зрештою, це - причина розвитку в людей із розладами психіки та поведінки внаслідок вживання 
алкоголю гемолітичного синдрому. У результаті наших досліджень виявлено специфічні особливості осмотичної резистентності еритроцитів у людей із зазначеними розладами психіки та поведінки, які полягають у прогресуючому зменшенні кількості дископодібних еритроцитів зі зниженням концентрації розчину хлориду натрію, що вказує на підвищену текучість мембранних білків (Najafipour \& Beik, 2016).

У патогенезі багатьох нозологічних одиниць, пов'язаних 3 уживанням алкоголю, першорядна роль надається не стільки самому терміну вживання алкоголю пацієнтами, як окисному стресу в різних клітинах. Еритроцити розглядаються багатьма авторами як пасивні «клітини-інформатори», проте залишаються мало вивченими (Renwick \& Asker, 2008). У процесі виконання одного із завдань даного дослідження, яке стосувалося питання, чи змінюється антиоксидантний стан еритроцитів у людей із розладами психіки та поведінки внаслідок вживання алкоголю та в якій мірі, ми показали, що в разі посилення окисного стресу в еритроцитах виявляється пониження активності глутатіонпероксидази за підвищення концентрації перекису водню та органічних гідропероксидів, із паралельним зниженням співвідношення глутатіон / глутатіондисульфід і активності глутатіонтрансферази.

Виявлена нами активація метаболізму еритроцитів, що проявляється накопиченням 2,3-дифосфогліцерату та лактату, може бути направлена не тільки на енергозабезпечення цих клітин i поліпшення оксигенації тканин шляхом зниження спорідненості гемоглобіну до кисню, а й на підтримку функціональної активності системи антиоксидантного захисту. Зокрема, відомо, що відновлений нікотинамідаденіндинуклеотид необхідний для реактивації супероксиддисмутази, що втратила активність у результаті накопичення неорганічних пероксидів (Miller, 2012). 3 урахуваннням того, що система антиоксидантного захисту виконує особливу роль у захисті еритроцитів від пошкодження в умовах високого парціального тиску кисню, ми визначили деякі ії показники, які вказують на приріст активності супероксиддисмутази та зменшення активності каталази. Таким чином, в еритроцитах людей із розладами психіки та поведінки внаслідок вживання алкоголю відбуваються протилежно направлені зміни активності супероксиддисмутази та каталази, що створює передумови для активації вільнорадикальних процесів.

Виявлене нами зростання вмісту глутатіону на фоні збільшення активності глутатіонредуктази служить для забезпечення функціонування глутатіонпероксидази. Враховуючи залежність глутатіонової системи від пулу відновленого нікотинамідаденіндинуклеотидфосфату та відновленого нікотинамідаденіндинуклеотиду, підвищення продукції лактату в еритроцитах, на наш погляд, відображає активацію гліколізу з метою захисту мембрани та гемового заліза від активних форм кисню. Виявлена динаміка показників свідчить про прооксидантне навантаження за вживання алкоголю та спроби компенсувати дисбаланс у першій лінії системи антиоксидантного захисту.

Треба зазначити, що проведення паралельних біохімічних, біофізичних і морфологічних досліджень еритроцитів розширює можливості встановлення глибини ураження організму, а також дає можливість широкому колу дослідників виявляти ефективність лікувально-профілактичних заходів для лікування алкоголізму та наркоманії.

\section{Висновки}

Дослідження кількісного складу еритроцитів і гемоглобіну, а також їх співвідношення в людей із розладами психіки та поведінки внаслідок вживання алкоголю виявило зниження кількості еритроцитів і гемоглобіну на 42,2\% і 25,1\% відповідно, що свідчить про наявність у них анемічної гіпоксії.

У людей із такими розладами психіки та поведінки відзначається зниження осмотичної стійкості еритроцитів до гемолізу за різної концентрації натрію хлориду.

Погіршення стану еритроцитарних мембран тісно корелює зі зменшенням розмірів еритроцитів, а також різними змінами їх мікрорельєфу. Понижена активність глутатіонпероксидази в еритроцитах має високу специфічність у всіх обстежених пацієнтів експериментальної групи, тому цей показник може служити новим маркером для таких людей, а зміни інших показників окисного стресу відображають неспецифічні порушення в організмі у відповідь на тривале вживання алкоголю.

\section{References}

Ainul, M., Badrul, M., \& Sultana, T. (2017). Efficient approach to detect hypochromic and normochromic anemia through image processing. Journal of Computer Applications, 159(2), 1-5.

Bergamini, C., Gambetti, S., Dondi, A., \& Cervellati, C. (2004). Oxygen, reactive oxygen species and tissue damage. Current Pharmaceutical Design, 10(14), 1611-1626.

Bianchini, K., \& Wright, P. A. (2013). Hypoxia delays hematopoiesis: Retention of embryonic hemoglobin and erythrocytes in larval rainbow trout, Oncorhynchus mykiss, during chronichypoxia exposure. Journal of Experimental Biology, 216(23), 4415-4425.

Billieux, J. (2014). Overview of internet addiction. Alcohol and Alcoholism, $49(1), 19$

Bunt, G. (2014). Nutritional and alternative interventions in addiction medicine. Alcohol and Alcoholism, 49(1), 31.

Chick, J. (2014). Recovery: Twelve simple steps to life beyond addiction. Alcohol and Alcoholism, 50(1), 103-105.

Eve, D., Steele, M., Sanberg, P., \& Borlongan, C. (2016). Hyperbaric oxygen therapy as a potential treatment for post-traumatic stress disorder associated with traumatic brain injury. Neuropsychiatric Disease and Treatment, 12(2), 2689-2705.

Foroughi, M., Maghsoudi, Z., \& Askari, G. (2016). The effect of vitamin D supplementation on blood sugar and different indices of insulin resistance in patients with alcoholic fatty liver disease (NAFLD). Iran Journal of Nurse Midwifery Research, 21(1), 100-104.

González-Alonso, J. (2012). ATP as a mediator of erythrocyte-dependent regulation of skeletal muscle blood flow and oxygen delivery in humans. Journal of Physioljgy, 590(20), 5001-5013.

Hafez, E., Hamad, M., Fouad, M., \& Abdel-Lateff, A. (2016). Auto-brewery syndrome: Ethanol pseudo-toxicity in diabetic and hepatic patients. Human and Experimental Toxicology, 4, 1-6.

Hajela, R. (2014). Assessment, diagnoses and treatment for addiction is addiction. Alcohol and Alcoholism, 49, 8-9.

Kayani, M. A., \& Parry, J. M. (2010). The in vitro genotoxicity of ethanol and acetaldehyde. Toxicology, 24(1), 56-60.

Khalsa, J. H. (2014). Nutrients, nutrition, nutrigenomics and nutrigenetics in addiction disorders. Alcohol and Alcoholism, 49(1), 31.

Ko, C. H. (2014). The next step of internet addiction in Taiwan. Alcohol and Alcoholism, 49(1), 39.

Koivu, S. (2014). Palliative care equality for people with IV drugaddiction. Alcohol and Alcoholism, 49(1), 65.

Koob, G. F. (2014). Addiction as a reward, stress and executive function disorder. Alcohol and Alcoholism, 49(1), 11.

Kurniasanti, K. S. (2014). Psychiatric trainee's perspective towards addictionin university of Indonesia. Alcohol and Alcoholism, 49(1), 53

Kutubi, A., Giles, S., \& Brennan, D. (2016). Investigating the effects of early embryonic ethanol exposure on primary cilium morphology. Reproductive Toxicology, 64, 46.

Leggio, L. (2011). Alcohol and tobacco. Medical and sociological aspects of use, abuse and addiction. Alcohol and Alcoholism, 46(3), 366.

Miller, R. R. (2012). Ethanol-induced lipid peroxidation and apoptosis in embryopathy. Alcohol, nutrition, and health consequences. Humana Press, New York.

Moskalewicz, J., Razvodovsky, Y., \& Wieczorek, L. (2016). East-west disparities in alcohol-related harm. Alcoholism and Drug Addiction, 29(4), 209-222.

Najafipour, H., \& Beik, A. (2016). The impact of opium consumption on blood glucose, serum lipids and blood pressure, and related mechanisms. Front Physiology, 7, 436-440.

Nielsen, D. A., Bahl, A. H. A., Varma, P., Kellogg, S., Borg, L., \& Kreek, M. J. (2012). Former heroin addicts with or without a history of cocaine dependence are more impulsive than controls. Drug and Alcohol Dependence, 124, 114-120.

Oslin, D. (2011). Personalized addiction treatment: How close are we? Alcohol and Alcoholism, 46(3), 231-232.

Raheb, G., Khaleghi, E. A., Moghanibashi-Mansourieh, F., Farhoudian, A., \& Teymouri, R. (2016). Effectiveness of social work intervention with a systematic approach to improve general health in opioid addicts in 
addiction treatment centers. Psychology Research Behaviour Management, 9, 309-315.

Rehm, J., \& Poznyak, V. (2015). On monitoring unrecorded alcohol consumption. Alcoholism and Drug Addiction, 28(2), 79-89.

Renwick, J. H., \& Asker, R. L. (2008). The time course of response of erythrocyte volume to ethanol and to its withdrawal. Clinical and Laboratory Haematology, 4(3), 325-326.
Welle-Strand, G. K. (2014). Norway: A new full specialty in addiction medicine. Alcohol and Alcoholism, 49(1), 13-14.

Wigmore, J. G. (2009). Blood ethanol concentrations are less stable than serum or plasma upon storage because of oxyhemoglobin-mediated oxidation of ethanol to acetaldehyde. Journal of Analytical Toxicology, 33(3), 182-183. 